Journal of Management and Economic
Studies
2019, 1(3): 1-9 DOI: $10.26677 / \mathrm{TR} 1010.2019 .92$
Journal Homepage: https://www.jomaes.org

\title{
Determinats of Self-Employment of Youth in Land Revoked Area in Vietnam: Overview and Analytical Framework
}

\author{
Dang Phi Truong \\ TNU - University of Economics \& Business Administration \\ $\mathrm{PhD}$ candidate, National Economics University
}

\begin{abstract}
This paper was conducted to build a model of factors affected self creating- job activities of youth in land recovered area in Vietnam. Base on adopted and modified the factors from previous researches in economic, labor and employment over pass 30 years, the determinants of self-employment of youth in land revoked were identified and used in the analytical framework proposal of author: Attitude, awareness of behavior controlling, opinion of family (subjective), source of finance and demographic characteristic.
\end{abstract}

Keywords: Self-employment, Attitude, Behavior - controlling awareness, Subjective standard, source of finance

\section{INTRODUCTION}

Creating-job in generally and especially for youth is an attention social-economic issue of almost countries in the world not excepting Vietnam. In Vietnam, every year, over one million of youth have enough age for become labor, and they are a significant source for developing this country. Thus, creating job is the most important target of Vietnam nowadays.

Researching on the theories and previous studies of factor affected to self creating-job of youth in land recovered area will provide more aspect of self-employment, factors affected to youth creating job. According to these findings, a proper researching frame work is built to evaluate level of determinants of self creating job for youth in recovered land in Vietnam.

By studying over thirty previous researches on economics, labor, employment in the world over thirty years, the factors influenced to self-employment were found out. Base on these findings, authors suggests that these group factors can affected to self creating job of youth of recovered land in Vietnam are: Attitude, awareness of behavior controlling, opinion of their family, financial resources and characteristic of demographic. This result will shed light on a more clear and proper framework for author and other research or the management when studying about this field in Vietnam. 


\section{LITERATURE REVIEW}

\section{Theories}

According to Ajzen (1991), Krueger et al (2000), start up is one planed behavior, while the nature of self-employment is also like a planed behavior so start up is similar with selfemployment. Like start-up, self-employment is discovering, using the opportunities of market but before making decision of self-employment, he or she has to thought, enjoyed, and has intent to making job, from that the will find opportunities, finance and partner to do his business. Self-employment is the result of personal awareness. Self-employment action will occur if an individual is positive, thoughtful, or intentional about this activity. A strong intention will always lead to an effort to start a new job, although job creation can be fast or slow due to the circumstances of the surrounding environment. Thus, the intention of selfemployment is capable of accurately predicting self-employment behavior in the future. Research on self-employment can reflect self-employment behavior. Explaining the start-up or self-employment process, researchers have developed and validated many models of start-up intention, which is the basis for the author's choice of a theoretical background for this study. Some typical theories are presented below.

Theory of social awareness (Bandura, 1986)

According to Bandura (1986), Ajzen (1991), Shapero and Sokol (1982) (re cited from Nguyen (2014)) from social cognitive theory and the theory of rational behavior, they argue that before going to perform a behavior, people must have intentions of that behavior. In the study of behavioral psychology, intent is the most accurate indicator of planned behavior, especially when behaviors are rare, difficult to observe and occur in unexpected time.

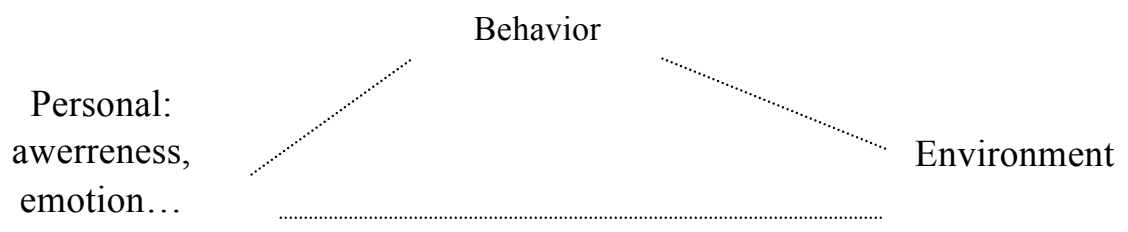

Theory of social awareness (Bandura, 1986

Evaluating the model value- attitude- behavior of Lavidge and Steiner (1961), (Homer and Kahle 1988) suppose that in this model value is considered "the most abstract concept of social perception," these values affect attitudes, followed by attitudes that influence behavior toward things, phenomena. Ajzen (1991) argues that the intention to perform a behavior is influenced by three factors: personal attitudes, subjective norms and behavioral awareness. An individual's attitude towards a behavior is how the individual feels when performing the behavior, which may be positive or negative. Subjective norms relate to how others (family, friends, etc.) feel when individuals perform such behavior. Behavioral controlling awareness refers to the perception of the ease or difficulty of performing the behavior, expressing the perception of the individual as being capable and sufficiently capable of performing the action.

Theory of Shapero and Sokol, 1982 (The entrepreneurial event - SEE)

Follow the entrepreneurial event model of Shapero and Sokol (1982), negative changes in life such as divorce, job loss, and job dissatisfaction ... are push factors or positive factors such as 
finding a good partner or having financial support... are pull factors. For example, a person fired, that factor will motivate him to do new business to self-control; or if he find a good business opportunity, even though his current job is not worth complaining about, he still can set up a new business.

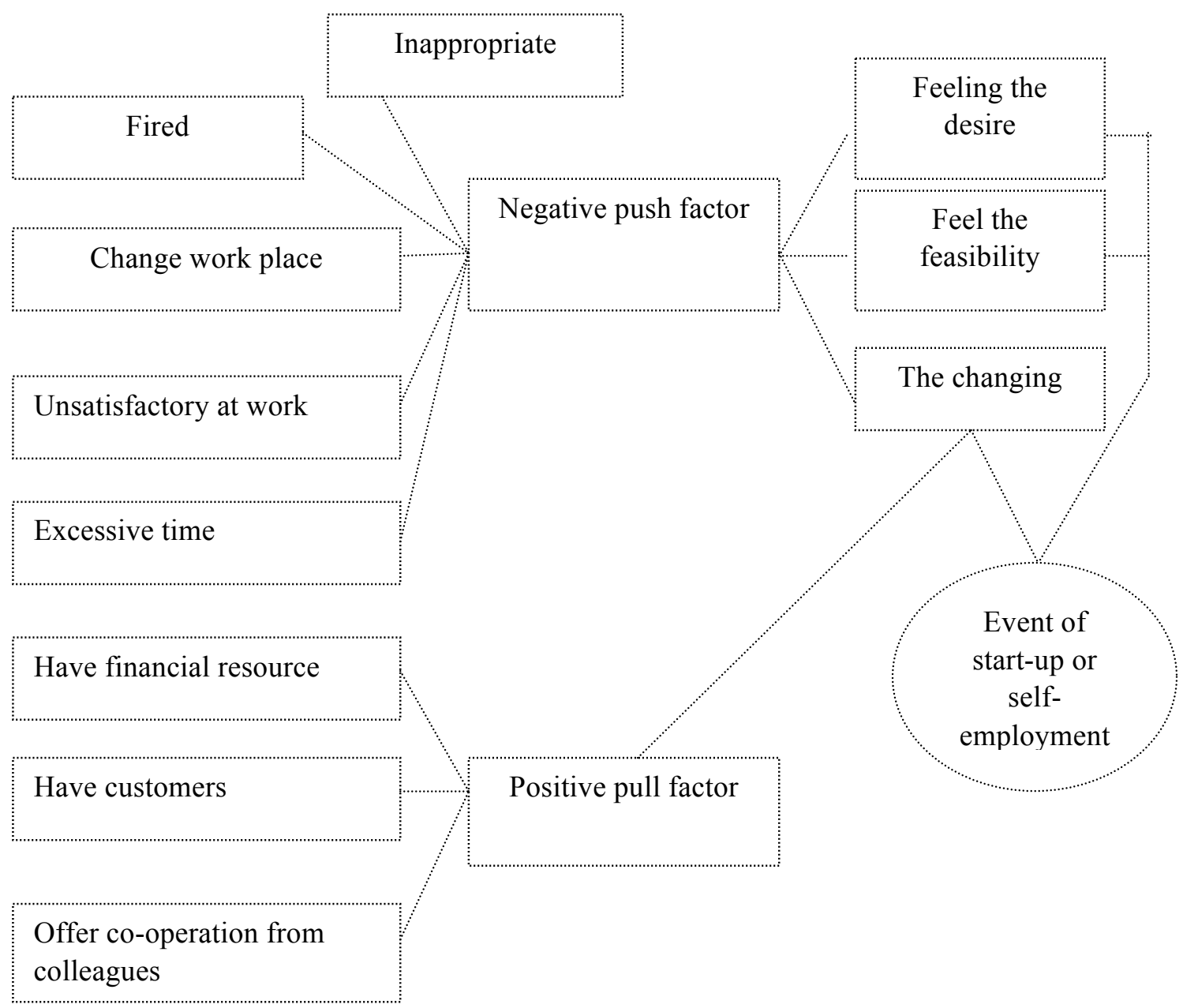

Model of start-up evention SEE (Shapero and Sokol, 1982)

Theory of planned behavior of Ajzen (1991)

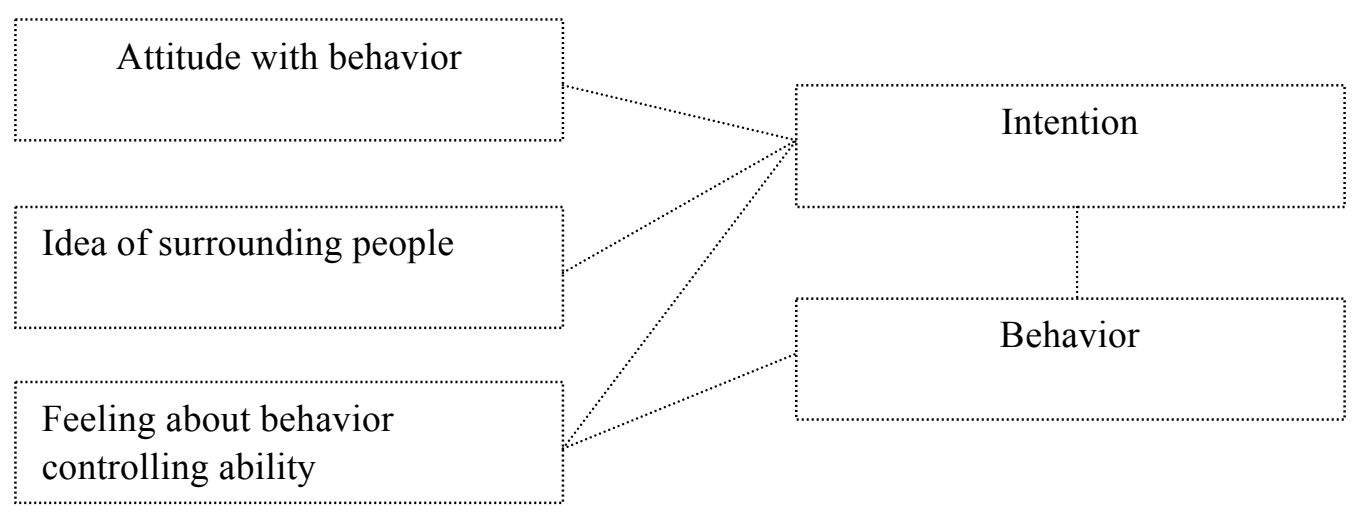

Theory of planned behavior TPB 
Ajzen (1991) suggested that human behavior is the result of intending to exercise behavior and ability to control of them. Intentional of doing behavior is influenced by three factors:

- Attitudes of individuals towards behavior - perceived attitude: expressing the positive or negative evaluation of individuals of self-employment. It's not only the feeling of the individual (I like it, it makes me feel good), but also it involves thinking about the value of selfemployment (it's potentially beneficial, there are more advantages) and "Do I want to do it?"

- Comments by people around (social norm): measure the feeling of an individual of social pressures when he chose whether or not conduct self-employment. In particular, it is an individual's feeling on whether people around him support his or her decision to create a job or choose a career; or answer the question "Do other people want me to do that?"

- Feeling about behavior controlling ability: is defined as an individual's perception of difficulty or easy in accomplishing behaviors (I find that I have the capacity and the resources to do that?). This concept is very close to Bandura's (1997) perception of self efficacy (SE) and also corresponds to the notion of feasibility (confidence) in the SEE model. Shapero and Sokol refer to the ability of an individual to complete the act of initiation. However, the perception of behavioral control differs from the notion of self-confident feeling in the perception that behavioral control is that not only a feeling of being able to perform the behavior is perceived but also having the ability to control behavior.

Model of intention Shapero - Krueger (2000)

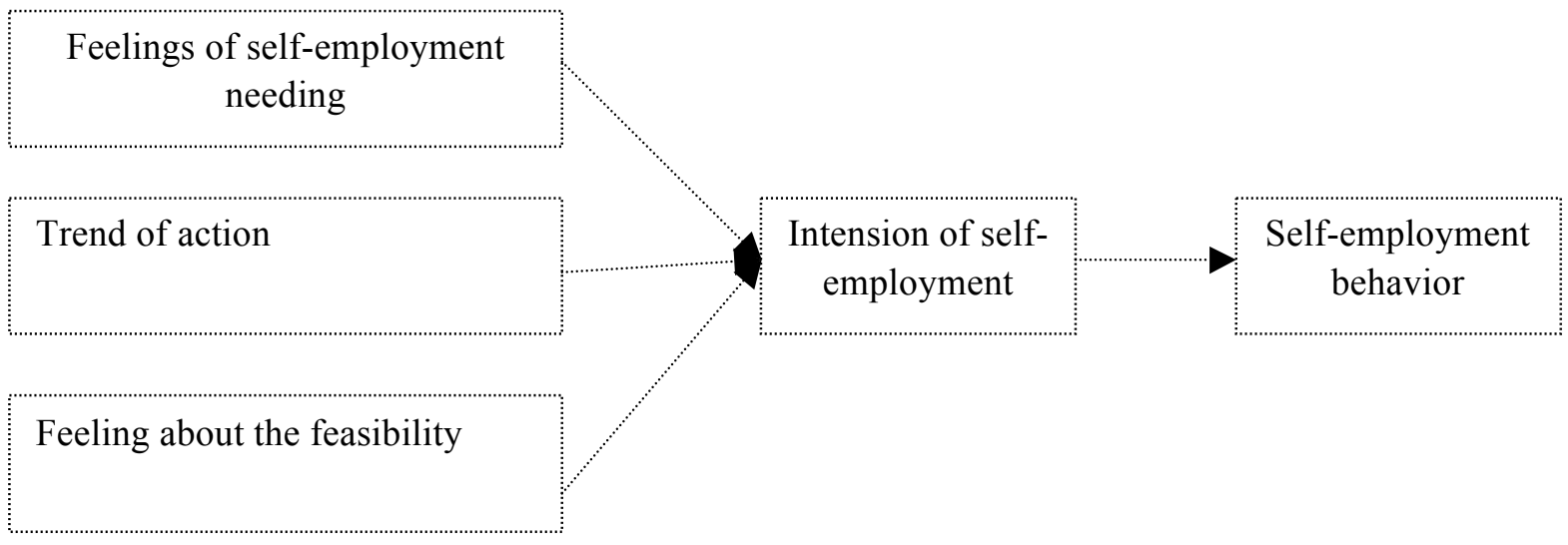

In the new model adapted from the SEE model of Shapero and Sokol, Krueger et al (2000) outlines three factors that affect an individual's intent. It is a desire, a sense of viability and a propensity to act. Basically, the model does not change much from the old model, the tendency of action is replaced by the change in life in the Shapero model. The tendency of action is the commitment of an individual to act upon the decision they made.

Theoretical models related to start-up, self-employment have similar characteristics. Intentional self-employment behavior is explained by personal ability and attitudes. Feeling confident or feasible in the SEE model is very close to the perception that behavioral control in the TBP model is derived from an individual's perception of self-efficacy. Feeling about the desire to start-up, self-employment is the combination of individual attitudes toward the behavior and the opinions of the people around whether they support or oppose their choice of selfemployment. Although different perspectives exist in the definition of variables, almost of the intended models allow for the integration of three key factors for self-employment: individual, 
environment, and resources to explain the cause of self-employment behavior, which is more advantages than the theory of personal qualities, excludes environmental factors in explaining self-employment behavior.

\section{Previous research}

\section{Self-Employment}

\section{Opinions about self-employment}

Study on "self-employment", which is an aspect of the concept of startup. In the field of academic research it is a multi-dimensional concept. Krueger et al (1994), start-up may t "start a new business" or "new venture creation, Lowell W. B. (2003), "entrepreneurship", Laviolette et al (2012) supposed that startup is self-employment. Thus, when one person startup, he can rent others people (play as a boss), or done by his self. In other words, self-employment can be understood as start-up a business, self-employment creation, like a boss, and find an income legally. If self-employment develops to a sufficiently large extent, people who start selfemployment, who can hire more labors, workers, and shift from self-employment to become a boss.

According to Krueger et al (2000) the framework theory of intention to start a business is similarly. Intention of startup was explained by personal ability and attitude. Feelings of business start-up confidence (feasibility) in the Entrepreneurial Event (SEE) model have similarities with the perception of behavioral control in theory of planned behavior (TBP) they are derived from the personal feeling of self-efficacy.

According to Linan, F. and Chen, Y.W. (2006), the career choice of those who are not afraid of risk is to own their own business and hire others to do business for them. Similarly, Kolvereid et al. (1996) also argue that "self-employment" is understood in the sense that it is opposed to employee of not own company, ie self-employment, self-employment, and can employ others for myself.

Research focuses on evaluating the role of self-employment

Sandeep Mohapatra et al (2006) investigated the role of self-employment in rural China, pointed out that the rise of self-employment promotes entrepreneurial spirit and that is sign of the development. The authors used data on labor market history for the 20 years from 1981 to 2001, and found evidence that there has been a rapid increase in the importance of self-employment in this period. Self-employment, which increased rapidly during the 1980s and 1990s, was characterized by significant changes in China's macro economy.

Studies in the world show that developed countries as well as developing countries have a lot of supportive policies and efforts to promote start-ups in youth, Malecki (1997), Reynolds (1994), Audretsch (2004) (cited in Carree and Thurik (2003)) Indicated that there is a close link between starting a business and regional and local economic growth. That is the reason why governments encourage students not to work as hired laborers, but to create jobs, increase the number of businesses for economic development. In Vietnam, the term "self-employment" often appears when it comes to encouraging start-ups of private enterprises or simply as a small business-to-business enterprise or create economic activities of households, family farms. Those who are encouraged or supported by "self-employment" in current state policies are mostly youth, women, the poor, job losers, the disabled. Le et al (2006) pointed out that local levels of government can create policies that enable workers to easily move their jobs in their own locality, or move to work in other localities, or do self-employment in their local.

\section{Research focuses on the factors that influence self-employment}


Ngo (2012), by micro approach, has tested the role of labor and social capital in ability to do self-employment of youth in Vietnam. The dependent variable is "self-employment"; The explanation variables are "human capital" (experience in the labor market, education level, training) and "social capital" (percentage of female members over 15 years of age in the household; self-employed in agriculture and non-farm work, occupation and employment of household head, education level and occupational skills of household head, material resources of the household, etc.). This study shows that the limitation of skills and qualifications is the main reason why the creating jobs of youth is difficult to effectively contribute to economic growth and development of the region and the country. In addition, by using qualitative methods, through the analysis of typical self-employment cases to build in-depth concepts of self-employment, determine the influencing factors and expectations to create jobs for young people and their needs in supporting of the creating jobs process. The author provided evidence of social capital through the supporting role of agencies, unions, organizations, Government and influential socio-economic development programs for youth groups whose do their self business or start-up. The author has also shown social capital through relationships and the support of the family is an important source of both physical and mental support for young people to create jobs. In addition, factors such as family tradition of self-employment, experience and support of other family members also play an important role in choosing selfemployment, do their own business. Ngo (2012) shows that although the family still plays an important role in supporting youth to create jobs, there is evidence that beside the family, the "network of social communication" which formed through participating in clubs, associations, seminars, seminars, forums ... as well as "associated social capital" obtained from the support of the Government and organizations In the country, especially the youth union has been effective for young people creating jobs in the current integration period and need to be promoted further. In addition Ngo (2012) also affirmed that two major barriers for young people when it comes to opportunities to create jobs and need to change are: (i) just consider creating jobs as a short-term solution when they lose their work or underemployment, this is not a career opportunity, (ii) instead of having "ideas" and "passion", young people still think that without capital they cannot create jobs themselves. In addition, the results found in Sandeep Mohapatra et al. (2007), based on quantitative research methods, also show that human capital and social capital affect self-employment, especially age, personality characteristics of parents.

Capital is also a factor which affected to ability of self-employment Kidd (1993), Bernhart (1994) found a significant effect of this factor on self-employment. They argue that difficulties in capital are barriers to self-employment, but there are also researches that financial capital is a motivational factor rather than a barrier. Do (2007) shows that the higher the income from external sources, the lower the ability to choose to create jobs, in which the source of outside income is money sent by relatives, real estate investment or financial investment. Tran (2012) summarized that the Vietnamese government has issued nearly 20 preferential credit policies, using credit lending mechanisms through programs and organizations, to support production capital for unluckily groups such as poor laborers, workers working abroad for a definite time, labor in the area of recovered agricultural land. Thereby, it can be seen that the financial issue for starting a business and creating jobs is one of the factors that significantly affect the selfemployment of young people in agricultural land recovery areas.

Phan \& Giang (2014) published a study on the factors affecting start-up, with research subjects are youths and students in Can Tho, applying the theory of planed behavior of Ajzen. The results of the study are determined based on data collected from 180 economic students graduated who have never start-up business and are living in Can Tho city. Research using Logistic factor analysis and Logistic binary regression, factors affecting the start-up intention are: Motivation to become an entrepreneur, Family background, Government policy and local , 
Entrepreneurship, Financial ability, Personal characteristics. However, the limitation of the study is that the survey sample is not large enough, the scope of research in a province so the results will be difficult to extrapolate and give policy suggestions for the whole country.

Ho (2015), if the rural workers rely on only their own financial capital to create non-farm jobs, the ability to create non-farm jobs is much lower than that of rural laborers who use a combination of different sources. The reaching on diversification capital sources of rural labor has a strong impact on the ability to create non-farm jobs. The study also demonstrates that the support of neighbors, friends and relatives has a great impact on the ability of rural workers to create non-farm jobs themselves. At the same time, the ability to share information also changes the ability of rural workers to create non-farm jobs This approach can fully consider the factors affecting the self-employment of rural workers such as age, gender, marital status, education level, professional level, and financial capital. Main self, health, vocational training (personal factors); household capital, factories and family land... (Elements of the household); organizations, support community capital, local policies, ability to share information (elements belonging to the community). However, in individual factors, the attitude, passion or desire of workers is not mentioned in this study. The research results also show that the role of the Youth Union and some other social organizations do not affect the self-employment of rural workers, this is also a point that needs to be the tested if research subjects can narrowing is the youth.

Summary of the above studies shows that much of the research on the topic of self-employment of young workers in general and related issues in Vietnam has been mentioned but at a level is relatively limited and these researches were used the traditional method is mainly. The in-depth analysis of the issue of self-employment, especially the factors affecting the self-employment of young people in the recovered land area in Vietnam still relatively small.

\section{METHODOLOGY}

This paper use desk research methodology to analyze, summary the theories, results of past studies in economic, labor, employment. The finding and collecting documents for review related to keywords: Employment, self-employment (self creating-job) so the choosing of papers are unlimited, and could be cited by other researchers. Studies refer to duplicate content being eliminated, and the remaining results are grouped.

\section{RESULTS}

Based on an overview of theory, along with previous studies, the author has proposed a research framework on factors affecting self-employment based on concepts and research hypotheses.

\section{Definition of self-employment}

Self-employment is the process of creating the necessary conditions for workers to combine with production materials and other conditions to conduct the labor process. There are three owners who can create jobs: the state, the employer, or the workers. If the workers themselves create conditions and combine with the means of production to conduct the work by themselves, the process is called self-employment.

\section{Factors affecting the job creation of young people in the recovered land in Vietnam}

Self-employment is a personal affair, a working attitude that promotes independence, autonomy, innovation and creativity, taking risks to create new value. Therefore, creating jobs is a decision in the whole process, not a decision of the moment. From the theoretical models presented above, the author inherits the conclusions that have been clarified, adds a number of factors and proposes the analytical framework as follows: 


\section{The assumptions}

$\mathrm{H}_{1}$ : "Feelings of wanting to create jobs" have a positive impact on the intention to create jobs $\mathrm{H}_{2}$ : The feeling of the feasibility of self-employment has a positive impact on the intention to create jobs

$\mathrm{H}_{3}$ : The role of family - relatives and friends positively impacts on the intention to create jobs $\mathrm{H}_{4}$ : Financial resources have positive affect to the intention of self-employment $\mathrm{H}_{5}$ : The intention to create jobs has an impact on self-employment

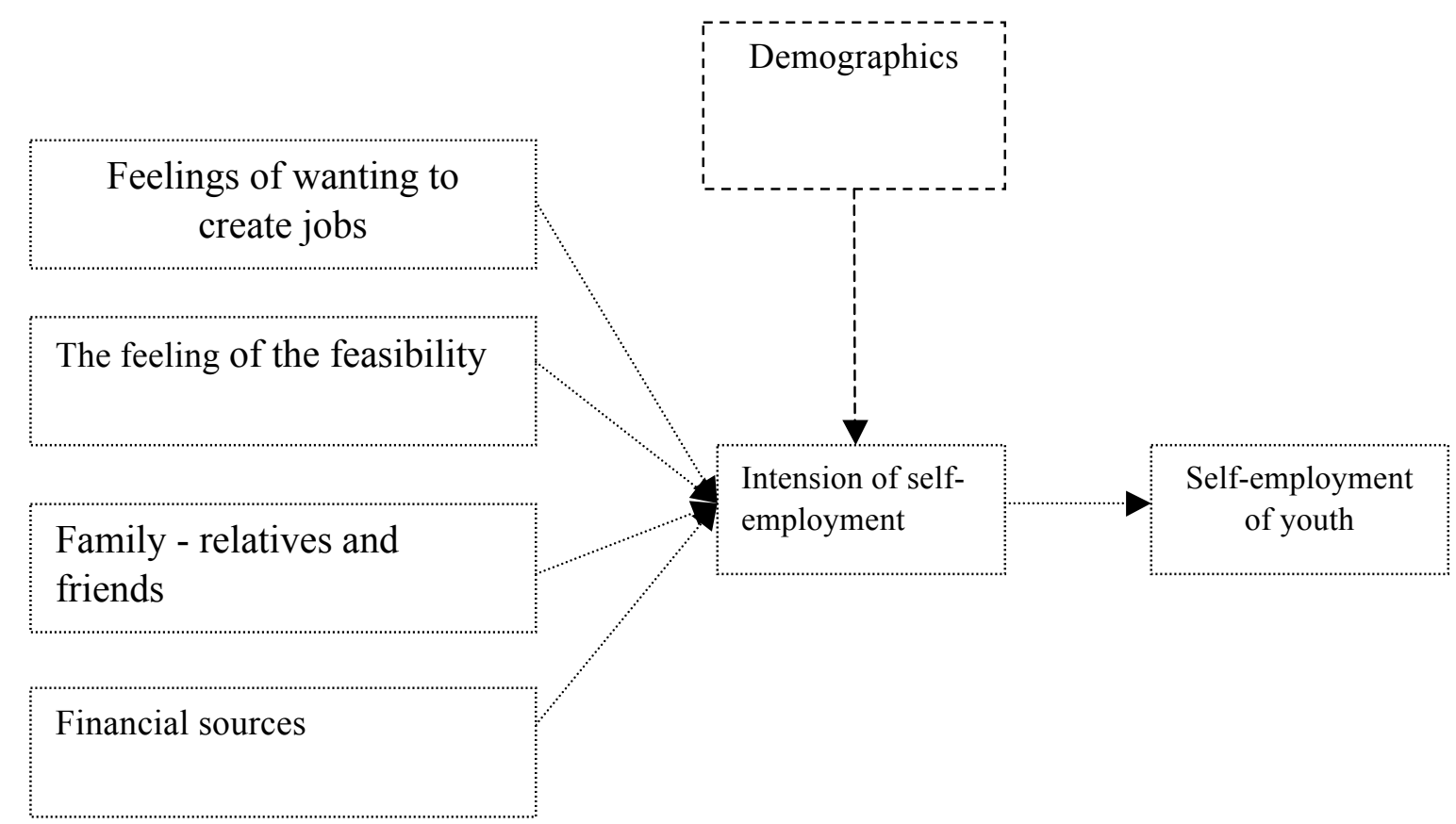

The findings which found out from testing assumptions in previous that there have the impact of the independent variables to start-up, so these findings shed-light on for studying topic selfemployment. Base on this model and using regression methodology can provide the empirical evidences about whether these assumptions are accept or not and can estimate the affection level of independent variables on the latent variable.

\section{CONCLUSION}

This research have provided model of determinants of self-employment of youth in Vietnam, this is basic model for implementing continued empirical researches of author, the found outs will cast-light on the solutions for resolving employment problems.

\section{REFERENCES}

Ajzen, I. (1991), The theory of planned behaviour. Organizational Behavior and Human Decision Processes, 50, $179-211$.

Bandura, A. (1986), "Social Foundations of Thought and Action: A Social Cognitive Theory", Englewood Cliffs, NJ: Prentice - Hall.

Carree, M. A., \& Thurik, A. R.(2003), "The impact of entrepreneurship on economics growth",The handbook of entrepreneurship research, D.B. Audretsch and Z.J. Acs (eds), Kluwer Academic Publishers, Boston/Dordrecht, pp: 437-471. 
Do Thi Quynh Trang, Genard Duchene (2008) "Determinant of sefl-employment: the case in Viet Nam, CES Working paper, University Paris 1, 2008.30p.

Ho Thi Dieu Anh (2015), Self-employment of rural labors in Nghe a province, Phd desertation, National Economics University.

Kolvereid, L. (1996a), “Organizational employment versus self-employment: Reasons for career intentions", Entrepreneurship Theory and Practice, 20(3), 23-31.

Krueger, N.F, Brazeal, D. (1994), "Entrepreneurial Potential and Potential Entrepreneurs", Entrepreneurship Theory and Practice, 18(3), pp91-104.

Krueger, N.F., Reilly, M.D., Carsrud, A.L.(2000), “Competing models of entrepreneurial intentions”, Journal of Business Venturing 15 (5/6), 411-432.

Lee M.A., Rendall M. (2001), Self-employment disadvantage in the working lives of blacks and females, Population Research and Policy Review 20: 291-320.

Linan, F. and Chen, Y.W. (2006), "Testing the entrepreneurial intention model on a two country sample", A Working Paper in the Documents de treball.

Ngo Quynh An (2011), Some factor affecting to self-employment of youth in Vietnam, Development economic article, volume 166.

Ngo Quynh An (2012), Enhance ability to creating job for youth in Vietnam, Phd Disertation, National economics university.

Nguyen Thu Thuy (2014), Factors impact to university students' entrepreneurship potential, Doctoral thesis, National Economics University

Phan Anh Tu, Giang Thi Cam Tien (2014), The research factors affect the intention to start a business: In the case of students of Faculty of Economics and Business Administration, journal of science of Can Tho University

Sandeep Mohapatra, Scott Rozelle, Rachael Goodhue (2006), The Rise of Self-Employment in Rural China: Development or Distress?, World Development Volume 35, Issue 1, January 2007, Pages 163-181.

Shapero, A. \& Sokol, L. (1982), "Social dimensions of entrepreneurship" in C.A. Kent, D.L. Sexton, E K.H. Vesper (Eds.), Encyclopedia of entrepreneurship, Englewood Cliffs, NJ: Prentice Hall, pp 72-90.

Singh,I., L.Squire and J.Strauss (1986), Agricultural Household Models. Extensions Applications, and Policy. The Johns Hopkins University Press, Baltimore and London.

Zhang J., Zhang L., Rozelle S., Boucher S. (2006), Self-employment with Chinese characteristics: the forgotten engine of rural China's growth, Contemporary Economic Policy, Vol. 24, No. 3, $446-458^{\prime \prime}$. 